CHRONIC OBSTRUCTIVE PULMONARY DISEASE

\title{
Chronic obstructive pulmonary disease in $\alpha_{1}$-antitrypsin PI MZ heterozygotes: a meta-analysis
}

\author{
C P Hersh, M Dahl, N P Ly, C S Berkey, B G Nordestgaard, E K Silverman
}

Thorax 2004;59:843-849. doi: 10.1136/thx.2004.022541

See end of article for authors' affiliations

.....................

Correspondence to: Dr E K Silverman, Channing Laboratory, Brigham and Women's Hospital, 181 Longwood Avenue, Boston, MA 02115, USA; ed.silverman@channing. harvard.edu

Received 29 January 2004 Accepted 3 April 2004

\begin{abstract}
Background: Severe $\alpha_{1}$-antitrypsin deficiency, usually related to homozygosity for the protease inhibitor (PI) Z allele, is a proven genetic risk factor for chronic obstructive pulmonary disease (COPD). The risk of COPD in PI MZ heterozygous individuals is controversial.

Methods: A search of MEDLINE from January 1966 to May 2003 identified studies that examined the risk of COPD in PI MZ individuals and studies that measured forced expiratory volume in 1 second $\left(\mathrm{FEV}_{1}\right)$ in heterozygotes.

Results: In 16 studies that reported COPD as a categorical outcome, the combined odds ratio (OR) for $\mathrm{PI} \mathrm{MZ}$ versus PI MM (normal genotype) was 2.31 (95\% $\mathrm{Cl} 1.60$ to 3.35). The summary OR was higher in case-control studies (OR 2.97; 95\% Cl 2.08 to 4.26 ) than in cross sectional studies (OR 1.50; $95 \% \mathrm{Cl} 0.97$ to 2.31 ) and was attenuated in studies that adjusted for cigarette smoking (OR $1.61 ; 95 \% \mathrm{Cl} 0.92$ to 2.81 ). In seven studies that reported $\mathrm{FEV}_{1}$ as a continuous outcome there was no difference in mean $\mathrm{FEV}_{1}$ between PI MM and PI MZ individuals.

Conclusions: Case-control studies showed increased odds of COPD in PI MZ individuals, but this finding was not confirmed in cross sectional studies. Variability in study design and quality limits the interpretation. These results are consistent with a small increase in risk of COPD in all PI MZ individuals or a larger risk in a subset. Future studies that adjust for smoking and include other COPD related phenotypes are required to conclusively determine the risk of COPD in PI MZ heterozygotes.
\end{abstract}

hronic obstructive pulmonary disease (COPD) is the fourth leading cause of death in the United States and a major cause of respiratory disability. ${ }^{1}$ Exposure to cigarette smoke is a well known environmental risk factor for COPD. Severe deficiency of $\alpha_{1}$-antitrypsin (AAT) is a proven genetic risk factor, but only $1-3 \%$ of all cases of COPD are estimated to be due to severe AAT deficiency. ${ }^{2}$

AAT is a serine protease inhibitor that protects the lung from the action of proteases, primarily neutrophil elastase. It is encoded by the polymorphic protease inhibitor (PI) locus on chromosome 14q32.1. The most common alleles are the normal $\mathrm{M}$ allele (95\% frequency in the US) and the deficient variants $\mathrm{S}(2-3 \%)$ and $\mathrm{Z}(1-2 \%)$. $^{3}$ Severe AAT deficiency is most commonly due to homozygosity for the $\mathrm{Z}$ allele (PI ZZ). Heterozygotes for the $\mathrm{Z}$ allele (most commonly PI MZ) have lower serum levels of AAT than normal individuals (PI MM) ${ }^{4}$ but the risk of lung disease in PI MZ individuals remains uncertain.

Although the risk of COPD in PI MZ heterozygotes has been analysed in many previous studies, the results have been inconsistent. ${ }^{5-7}$ In general, case-control studies have found an increased prevalence of PI MZ heterozygosity in COPD patients. However, PI MZ individuals identified from population surveys have not consistently been found to have higher rates of airflow obstruction than PI MM individuals. With an estimated six million PI MZ individuals in the US and over 10 million in Europe, determination of the COPD risk in PI MZ individuals may have broad public health implications. ${ }^{8}$ We therefore performed a systematic review of the medical literature to examine the risk of COPD in AAT PI MZ heterozygotes.

\section{METHODS}

Study selection

A search of MEDLINE was performed to identify all studies that examined the risk of COPD or that measured pulmonary function in AAT PI MZ heterozygotes published between January 1966 and May 2003 using the medical subject headings " $\alpha_{1}$-antitrypsin", " $\alpha_{1}$-antitrypsin deficiency", "protease inhibitors", "obstructive lung diseases", "chronic obstructive pulmonary disease", "pulmonary emphysema", "forced expiratory volume", "respiratory function tests", and "spirometry". Bibliographies of pertinent articles and reviews were searched for additional references.

Two investigators independently evaluated studies for inclusion ( $\mathrm{CPH}, \mathrm{MD})$. Disagreements were resolved by discussion including a third author (EKS). Included studies were case-control, cohort, and cross sectional studies using the categorical outcome of COPD based on spirometry or a physician's diagnosis. Studies reporting forced expiratory volume in 1 second $\left(\mathrm{FEV}_{1}\right)$ as a continuous outcome measure were also included. In the case-control design, comparison with controls from a previously published report was permitted as long as the cases and controls were from the same country and the same method was used for determination of PI type. In all included studies, PI type had to be determined using isoelectric focusing, acid starch gel with crossed immunoelectrophoresis, or a polymerase chain reaction (PCR) based genotyping method.

Studies defining heterozygotes based on serum AAT levels or functional activity were excluded since PI MZ heterozygotes could not be consistently distinguished from other genotypes. Family studies and studies of children only were also excluded. For the continuous outcome, studies that did not present $\mathrm{FEV}_{1}$ as a percentage of the predicted value were analysed separately. We also attempted to exclude duplicate analyses of the same population of cases.

\section{Study quality}

A global assessment of the quality of each study was made, based on the following criteria: (1) Was the phenotype of obstructive lung disease defined by objective spirometric 
indices? (2) Were the cases and controls (in case-control studies) or the PI MZ and PI MM individuals (in population based studies) matched on ethnicity? (3) Did the studies control for cigarette smoking? (4) Did the authors test for Hardy-Weinberg equilibrium in the controls (case-control design) or in the population (cross sectional design)?

The quality of a study was not a factor in its inclusion, except when the cases and controls were derived from studies in different countries as mentioned above. The quality criteria were used for the subgroup analyses.

\section{Data analysis}

Two investigators independently extracted data from each study. When studies determined COPD both by spirometric criteria and by physician diagnosis, the spirometric definition was used. Due to the small number of longitudinal studies, only the baseline cross sectional data from cohort studies were used. The effect estimates were combined using the random effects method of DerSimonian and Laird. ${ }^{9}$ All analyses were performed using STATA release 8 (STATA Corp, College Station, TX, USA). The Q-statistic was used to assess for heterogeneity among studies.

Funnel plots and weighted regression were used to search for publication bias. ${ }^{10}$ Subgroup analyses were used to examine three potentially important sources of heterogeneity. The predetermined subgroups were based on study design, use of spirometric criteria to define COPD, and adjustment for cigarette smoking. The stability of the summary risk estimate was evaluated using a sensitivity analysis; each study was individually removed and the odds ratio (OR) was recalculated.

The studies that reported $\mathrm{FEV}_{1}$ as a continuous outcome were analysed separately. A summary difference in mean $\mathrm{FEV}_{1}$ between PI MM individuals and PI MZ individuals was calculated using the random effects model.

\section{RESULTS}

\section{Search results and study eligibility}

The initial search yielded 1125 references. From these, 106 studies were retrieved for detailed review and 22 were selected for primary analysis (tables 1 and 2). ${ }^{1-32}$ Sixteen studies were case-control or cross sectional studies with the binary outcome of COPD or airflow obstruction. Seven cross sectional studies measured $\mathrm{FEV}_{1}$ (\% predicted) as a continuous outcome; four additional studies reported $\mathrm{FEV}_{1}$ in litres and were used for confirmatory analysis. One study included both the continuous and categorical outcome measures and was included in both analyses. ${ }^{15}$

The reasons for exclusion were: determination of PI type by suboptimal methods $(\mathrm{n}=14),{ }^{33-46}$ reviews, editorials, or conference proceedings $(\mathrm{n}=13),{ }^{58}{ }^{47-57}$ absence of an adequate control group $(\mathrm{n}=11),{ }^{45}$ 58-67 measured pulmonary function tests other than $\mathrm{FEV}_{1}(\mathrm{n}=10),{ }^{68-77}$ analysed other PI types but not PI MZ $(n=10),{ }^{56} 5778-85$ recorded $\mathrm{FEV}_{1}$ as an absolute volume and not as percentage of predicted $(n=9$, of which four were included in a separate analysis), ${ }^{86-94}$ did not differentiate PI MZ from other variant genotypes $(\mathrm{n}=8),{ }^{879095-100}$ used AAT level to define the exposure or the outcome $(\mathrm{n}=8),{ }^{44}{ }^{47}{ }^{101-106}$ COPD defined by self-report or hospital discharge records $(\mathrm{n}=3),{ }^{88} 107108$ duplicate studies in the same population of cases $(n=3),{ }^{109-111}$ children only $(\mathrm{n}=3),{ }^{97} 112113$ and family based study design $(\mathrm{n}=2) \cdot{ }^{114}{ }^{115}$ Some studies were excluded for more than one reason.

\section{Study quality}

The quality criteria fulfilled by each study are shown in tables 1 and 2. Nine studies used specific spirometric criteria to define COPD; ${ }^{11} 12151723-253031$ these criteria were usually based on a reduced value for the $\mathrm{FEV}_{1}$ and/or the ratio of
$\mathrm{FEV}_{1}$ to forced vital capacity (FVC). The other seven studies used clinical diagnoses which may have included pulmonary function testing, but explicit criteria were not stated. By definition, spirometry was recorded in all seven studies that reported mean $\mathrm{FEV}_{1}$ as the outcome measure.

Most of the case-control studies derived their controls from local sources; only two studies used blood donors as controls. In most of the cross sectional studies the PI MM and PI MZ individuals were derived from the same source population. Four of the North American studies were restricted to Caucasian subjects ${ }^{11} 142630$ and one matched cases and controls by ethnicity. ${ }^{17}$ Six studies were conducted in European nations where ethnic homogeneity is likely. ${ }^{13} 1518202429$ Among the studies that examined FEV as a continuous outcome, only one of the four North American studies was restricted to Caucasians. ${ }^{28}$ Three studies measuring $\mathrm{FEV}_{1}$ as a continuous outcome were done in Europe. ${ }^{151619}$ None of the included studies explicitly addressed population stratification-for example, by testing a panel of unlinked markers. ${ }^{116}$

In the categorical analysis of COPD in case-control and cross sectional studies, five studies controlled for cigarette smoking. ${ }^{11} 15232530$ Kueppers and coworkers ${ }^{25}$ matched cases and controls on smoking history categorised into nonsmokers, moderate smokers, and heavy smokers based on lifetime pack-years smoked. Two studies stratified by smoking status. Klayton $e t \mathrm{al}^{23}$ divided subjects into never versus ever smokers, and Chan-Yeung et al ${ }^{11}$ into non-smokers, exsmokers, and current smokers. The study by Dahl et al ${ }^{15}$ used logistic regression modelling to control for smoking status. One additional study used logistic regression but the resulting OR was not presented; ;0 for our analysis, the OR was calculated by adding a correction factor of 0.5 to all cells to account for a zero cell. In the analysis of mean $\mathrm{FEV}_{1}$ as a continuous outcome, four studies controlled for cigarette smoking. Hall and colleagues ${ }^{21}$ restricted the study to nonsmokers. Eriksson and coworkers ${ }^{16}$ performed a stratified analysis, presenting mean $\mathrm{FEV}_{1}$ values for smokers, exsmokers, and non-smokers. In the studies by Girard et $a l^{19}$ and Horne et $a^{22}$ PI MZ and PI MM individuals were matched by smoking status.

In the study by Dahl and colleagues ${ }^{15}$ a test of HardyWeinberg equilibrium was performed; in this population sample the observed genotype frequencies did not differ from those predicted under Hardy-Weinberg equilibrium. In no other study did the authors report testing for HardyWeinberg equilibrium. Based on the predetermined criteria, the majority of studies were judged to be of suboptimal quality. The study by Dahl and coworkers ${ }^{15}$ was the only one that met all four of the predefined quality criteria.

\section{Odds ratio (OR) for COPD in PI MZ heterozygotes}

Six of the 16 studies examining the categorical outcome of obstructive lung disease found significantly higher ORs for COPD in PI MZ heterozygotes than in PI MM individuals (fig 1). In nine other studies the OR was increased, but not significantly. One study found a reduced OR, but not significantly. The individual study ORs ranged from 0.15 to 16.78. Using the random effects method, ${ }^{9}$ the summary OR for COPD in PI MZ compared with PI MM individuals was significantly increased at 2.31 (95\% CI 1.60 to 3.35 ).

Significant heterogeneity was detected among the studies ( $Q$ test: $\chi_{15 \mathrm{df}}^{2}=36.1, \mathrm{p}=0.002$ ). Subgroup analyses are shown in fig 2 . In a subgroup analysis based on study design, the 11 case-control studies were found to have a larger summary OR than the five cross sectional categorical studies (case-control OR 2.97, 95\% CI 2.08 to 4.26; cross sectional OR $1.50,95 \%$ CI 0.97 to 2.31 ). There was less heterogeneity within each of these subgroups than in the 
Table 1 Studies examining risk of COPD in $\alpha_{1}$-antitrypsin PI MZ heterozygotes

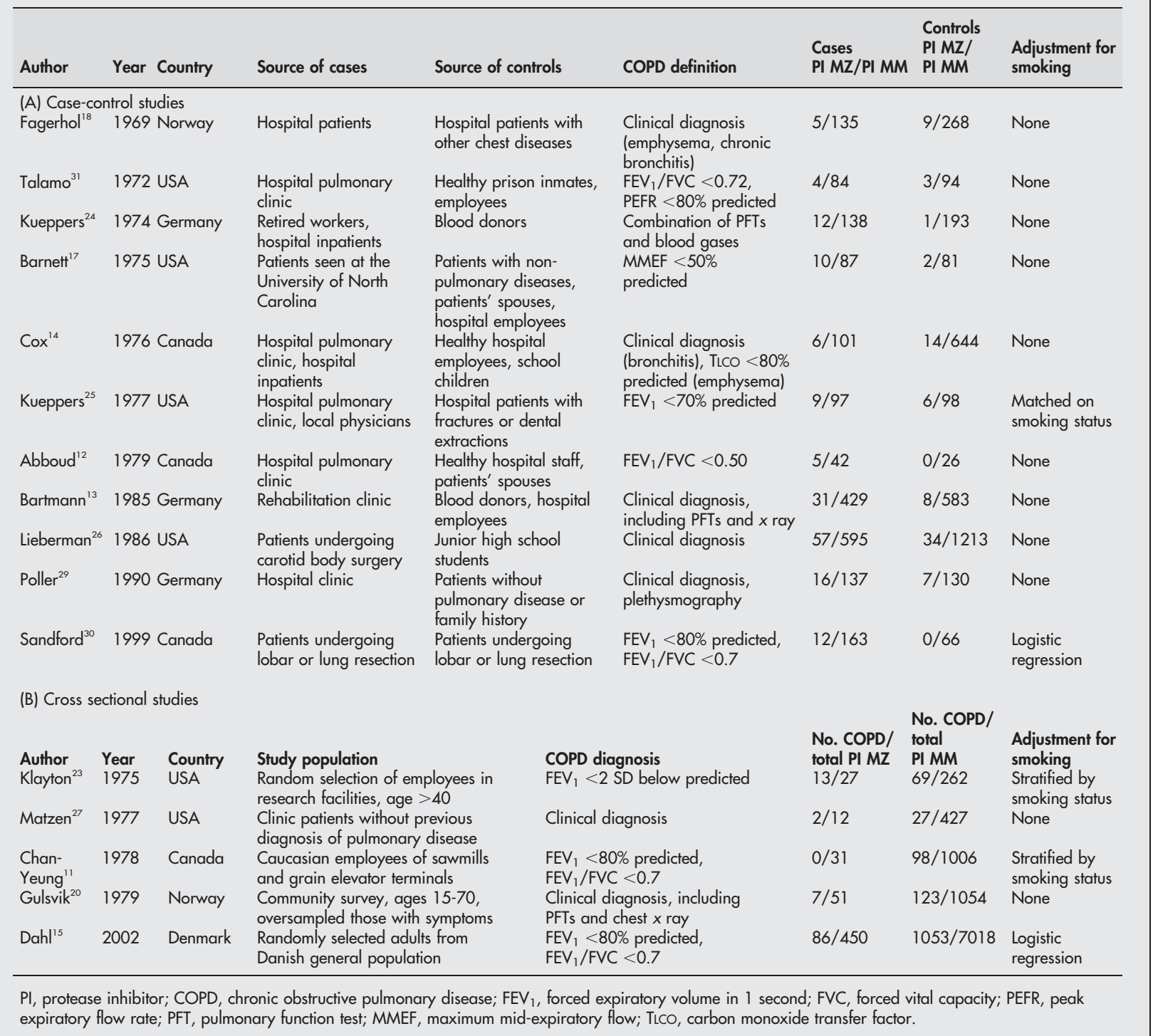

Table 2 Studies reporting $\mathrm{FEV}_{1}$ (\% predicted) in $\alpha_{1}$-antitrypsin PI MZ heterozygotes

\begin{tabular}{|c|c|c|c|c|c|c|c|c|}
\hline Author & Year & Country & Study population & $\begin{array}{l}\text { No. } \\
\text { PI MM }\end{array}$ & $\begin{array}{l}\text { Mean } \mathrm{FEV}_{1} \\
\text { (\% predicted) }\end{array}$ & $\begin{array}{l}\text { No. } \\
\text { PI MZ }\end{array}$ & $\begin{array}{l}\text { Mean } \mathrm{FEV}_{1} \\
\text { (\% predicted) }\end{array}$ & Adjustment for smoking \\
\hline Webb ${ }^{32}$ & 1973 & USA & $\begin{array}{l}\text { Consecutive patients at an early } \\
\text { disease detection unit }\end{array}$ & 395 & 92.0 & 18 & 102.0 & None \\
\hline $\mathrm{Hall}^{21}$ & 1976 & USA & $\begin{array}{l}\text { Matched pairs identified from } \\
\text { patients at an early disease detection } \\
\text { unit }\end{array}$ & 15 & 107.0 & 15 & 110.0 & Restricted to non-smokers \\
\hline Morse ${ }^{28}$ & 1977 & USA & $\begin{array}{l}\text { Population sample of Caucasians in } \\
\text { Tuscon, Arizona }\end{array}$ & 2637 & 96.0 & 88 & 94.5 & None \\
\hline Girard $^{19}$ & 1978 & France & $\begin{array}{l}\text { Matched pairs from a population } \\
\text { sample of men in Nancy }\end{array}$ & 24 & 92.0 & 24 & 91.7 & $\begin{array}{l}\text { Matched on smoking } \\
\text { status }\end{array}$ \\
\hline Eriksson $^{16}$ & 1985 & Sweden & $\begin{array}{l}\text { Matched pairs from a random } \\
\text { sample of } 56 \text { year old men in } \\
\text { Malmo }\end{array}$ & $\begin{array}{l}14 \\
4 \\
13\end{array}$ & $\begin{array}{l}99.0 \text { (smokers) } \\
111.0 \text { (ex) } \\
105.0 \text { (non) }\end{array}$ & $\begin{array}{l}14 \\
6 \\
12\end{array}$ & $\begin{array}{l}96.0 \text { (smokers) } \\
105.0 \text { (ex) } \\
104.0 \text { (non) }\end{array}$ & $\begin{array}{l}\text { Stratified by smoking } \\
\text { status }\end{array}$ \\
\hline Horne $^{22}$ & 1986 & Canada & $\begin{array}{l}\text { Matched pairs of male grain } \\
\text { workers in Saskatchewan }\end{array}$ & 28 & 104.0 & 28 & 94.0 & $\begin{array}{l}\text { Matched on smoking } \\
\text { status }\end{array}$ \\
\hline Dahl $^{15}$ & 2002 & Denmark & $\begin{array}{l}\text { Population sample in Copenhagen } \\
\text { (baseline data from longitudinal } \\
\text { study) }\end{array}$ & 7037 & 90.0 & 451 & 91.0 & Not for $\mathrm{FEV}_{1}$ data \\
\hline
\end{tabular}




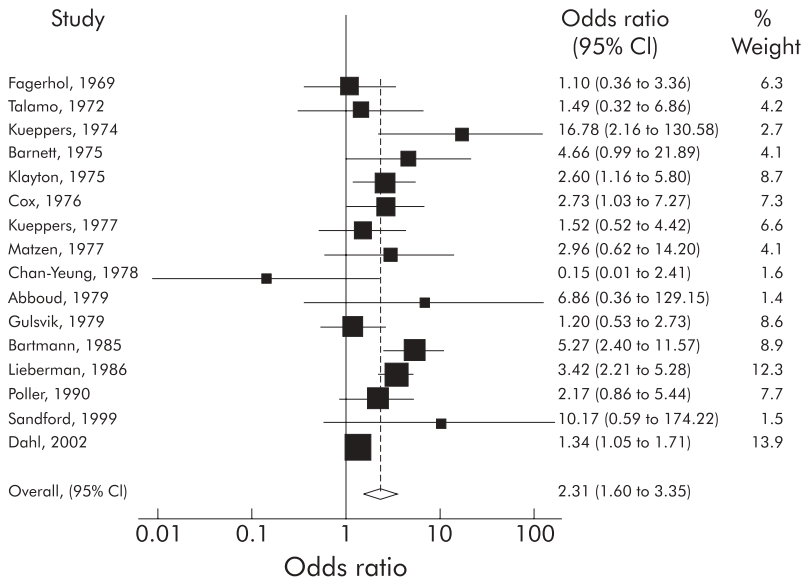

Figure 1 Case-control and cross sectional studies of COPD in $\alpha_{1}$ antitrypsin PI MZ heterozygotes. Sizes of boxes represent inverse variance weights (random effects model). ${ }^{9}$ Lines represent $95 \%$ confidence intervals.

combined analysis (case-control $\chi^{2}{ }_{10 \mathrm{df}}=12.3, \mathrm{p}=0.27$; cross sectional $\chi_{4 \mathrm{df}}^{2}=5.9, \mathrm{p}=0.21$ ).

The magnitude of the effect estimate was similar in the nine studies that used spirometric criteria for the definition of obstructive lung disease (OR 2.17, 95\% CI 1.22 to 3.87) and the seven studies that relied on clinical diagnoses of COPD (OR 2.52, 95\% CI 1.65 to 3.85); heterogeneity was reduced, but still possible, within each of these subgroups as well ( spirometric criteria $\chi_{8 \mathrm{df}}^{2}=15.4, \mathrm{p}=0.051$; no spirometric criteria $\left.\chi_{6 \mathrm{df}}^{2}=10.3, \mathrm{p}=0.11\right){ }^{117}$

The magnitude of the effect estimate was lower in the five studies that adjusted for cigarette smoking (OR 1.61, 95\% CI 0.92 to 2.81 ) than in the 11 studies that did not (OR 2.73 95\% CI 1.86 to 4.01 ); in the studies that stratified by smoking status, data were pooled across each stratum for analysis. Again, heterogeneity was reduced within each of these subgroups (adjustment for smoking $\chi_{4 \mathrm{df}}^{2}=6.8, \mathrm{p}=0.15$; no adjustment for smoking $\left.\chi_{10 \mathrm{df}}^{2}=14.7, \mathrm{p}=0.14\right)$. Due to the different methods used to control for smoking in the different studies, separate summary ORs for smokers and non-smokers could not be derived.

In the sensitivity analysis, when the study by Dahl et al ${ }^{15}$ was removed from the analysis, the summary OR was increased above that obtained using all 16 studies. When each of the other 15 papers was removed individually, the summary OR was unchanged. The funnel plot of OR versus standard error (both log transformed) appeared to be symmetrical, and the regression method of Egger et al ${ }^{10}$ did not indicate significant evidence for publication bias $(\mathrm{p}=0.15)$.

\section{Mean $\mathrm{FEV}_{1}$ in PI MZ heterozygotes compared with normal subjects}

The seven cross sectional studies that compared mean $\mathrm{FEV}_{1}$ (\% predicted) in PI MM and PI MZ individuals are shown in table 2. One study from the categorical outcome analysis also reported mean values for $\mathrm{FEV}_{1}$ and was included in the continuous outcome analysis. ${ }^{15}$ For the one study that reported mean $\mathrm{FEV}_{1}$ values stratified by smoking status, data from the individual strata were entered into the analysis. ${ }^{16}$ In the pooled analysis (fig 3) there was no difference in mean $\mathrm{FEV}_{1}$ (\% predicted) between PI MM and PI MZ individuals (summary difference PI MM PI $M Z=0.62 \%$ predicted, $95 \%$ CI -2.30 to 3.54$)$. Significant heterogeneity was detected in these studies $\left(\chi^{2} 8 \mathrm{df}=24.4\right.$, $\mathrm{p}=0.002$ )

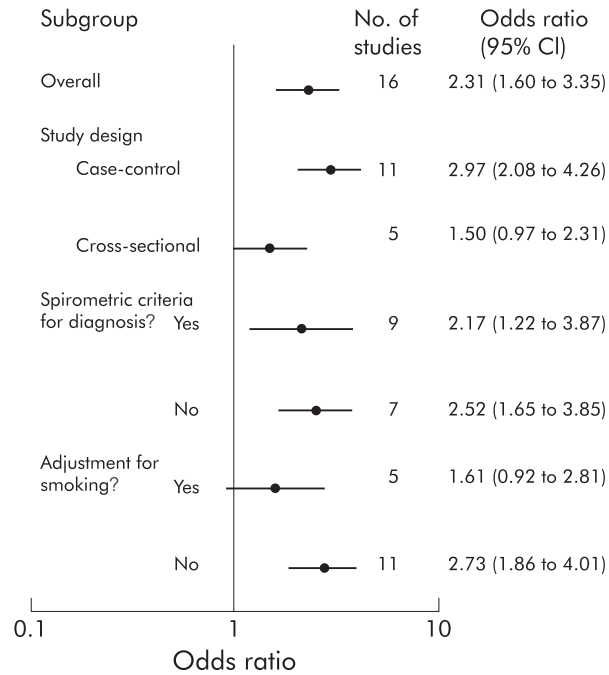

Figure 2 Subgroup analysis of studies of COPD in $\alpha_{1}$-antitrypsin PI MZ heterozygotes. Odds ratios with $95 \%$ confidence intervals are shown.

No asymmetry was detected in the funnel plot of the difference in mean $\mathrm{FEV}_{1}$ versus standard error. Egger's test did not reveal significant publication bias $(p=0.71)$. In the sensitivity analysis the mean difference in $\mathrm{FEV}_{1}$ was increased when the study by Dahl et al ${ }^{15}$ was removed; the mean difference was unaffected when each of the other studies was excluded. Because of the small number of studies, no subgroup analyses were performed for the mean differences in $\mathrm{FEV}_{1}$. A separate analysis of four cross sectional studies that expressed $\mathrm{FEV}_{1}$ in litres (but otherwise met inclusion criteria) was performed..$^{89} 919394$ There was no difference in mean $\mathrm{FEV}_{1}$ between PI MM and PI MZ individuals (summary difference PI MM - PI MZ $=-0.01$ litres, $95 \%$ CI -0.23 to 0.21 ).

\section{DISCUSSION}

We have conducted a systematic review of the medical literature to evaluate the risk of COPD in AAT PI MZ heterozygotes. Combining studies reporting a categorical outcome, we found moderately increased odds of obstructive

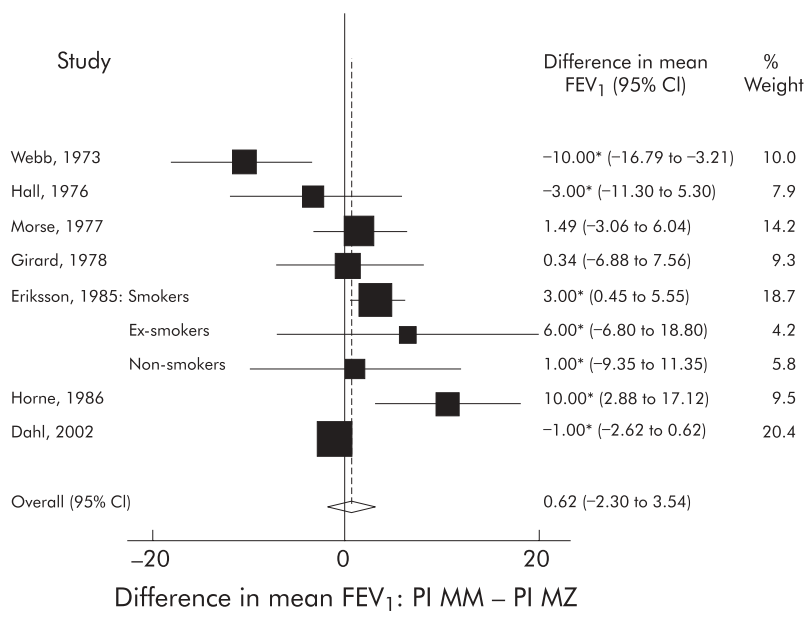

Figure 3 Studies reporting $\mathrm{FEV}_{1}$ as percentage predicted in $\alpha_{1}$ antitrypsin PI MZ heterozygotes. The mean difference is calculated by subtracting the mean $\mathrm{FEV}_{1}$ (\% predicted) of PI MZ individuals from that of PI MM individuals. Sizes of boxes represent inverse variance weights (random effects model). ${ }^{9}$ Lines represent $95 \%$ confidence intervals.

*Presented mean $\mathrm{FEV}$, to the nearest percent. 
lung disease in PI MZ individuals (OR 2.31). As has been noted in previous narrative reviews, the effect estimate was larger in the case-control studies than in the cross sectional studies. ${ }^{67}$ The magnitude of the OR was attenuated in the studies that adjusted for cigarette smoking, but was not substantially different in the subgroup of studies that used objective spirometric criteria to define COPD. The studies measuring lung function as a continuous outcome did not show a difference in mean $\mathrm{FEV}_{1}$ (\% predicted) between PI MM and PI MZ individuals.

Overall, the study quality was variable. Only one study fulfilled all four of the quality criteria. The differences in study design and quality, including adjustment for cigarette smoking, probably contribute to the significant heterogeneity found among the studies in the analyses of both the categorical and continuous outcome measures. These studies were all observational, so they are all susceptible to a variety of biases. Some of the studies used different sources for the cases and controls (or PI MM and PI MZ individuals), leading to the possibility of selection bias. Only one study tested for Hardy-Weinberg equilibrium; deviations from Hardy-Weinberg equilibrium could be indicative of problems such as genotyping error or population stratification. ${ }^{118}$

Confounding by environmental exposures is another potential concern in observational studies. Cigarette smoking is the major environmental risk factor for COPD, but many of the studies did not adjust for smoking as a potential confounder. This is a likely source of heterogeneity between studies. Other potential confounders may also be important, yet control for factors such as age and sex was also inconsistent. In the analysis of lung function as a continuous outcome, the primary analysis included studies that expressed $\mathrm{FEV}_{1}$ as a percentage of predicted since the equations used to calculate the predicted values adjust for important covariates-namely, age, sex, and height. Although different studies used different prediction equations, the same equations were used for both the cases and the controls within an individual study.

A strict phenotype definition is necessary for genetic epidemiology studies, ${ }^{118}$ but not all of the studies used objective spirometric criteria for the diagnosis of COPD. This may also be a source of heterogeneity between studies. Although the inclusion criteria allowed for different methods of assessment of PI type, this should not lead to important heterogeneity since the included methods are generally quite reliable. ${ }^{119}$

The divergent conclusions reached by the analyses of the categorical and continuous outcomes require further investigation. Overall, the categorical studies-specifically the case-control studies-showed an increased risk of COPD yet no reduction in mean $\mathrm{FEV}_{1}$ was seen in PI MZ individuals in the cross sectional lung function studies. If PI MZ heterozygosity is a risk factor for COPD, one would expect to find both an increased OR in the categorical studies and a reduction in lung function in the studies measuring continuous outcome; reduced $\mathrm{FEV}_{1}$ is a defining feature of COPD.

If the overall risk increase in PI MZ individuals is uniform but small, then case-control studies may detect this risk more efficiently than cross sectional studies. ${ }^{120}$ Among the categorical studies, the case-control studies did show an increased OR but the cross sectional categorical studies showed only a trend towards increased risk of COPD in PI MZ individuals.

Alternatively, these results are consistent with an increased risk of COPD in a subgroup of PI MZ individuals. Cigarette smoking may be an important co-factor, and many of the published population based studies may not be large enough to detect this genotype-by-environment interaction. Other genetic factors are likely to modify the risk of development of lung disease in PI ZZ homozygotes, ${ }^{114}{ }^{121}$ and it is possible that genetic modifiers of lung disease in PI MZ individuals also exist.

The results of a recent cohort study are consistent with a modifier of COPD risk in PI MZ individuals. Among 1551 PI MZ subjects from the Danish Alpha 1-Antitrypsin Deficiency Registry, the relative risk for hospital admission for obstructive lung disease (asthma, emphysema, or chronic bronchitis) was twice that of population controls. ${ }^{107}$ First degree relatives of PI Z index cases, with the index cases identified based on respiratory symptoms, were the subgroup responsible for this increased risk. This suggests the presence of other genetic and/or environmental factors aggregating in the families of the PI Z index cases.

Based on this systematic review, the risk of COPD in PI MZ heterozygotes remains uncertain. However, a small increase in risk for all PI MZ individuals or a larger increase in risk in a subgroup of heterozygotes are possible explanations for the apparently discordant results from the analyses of the categorical (especially the case-control studies) and continuous outcome measures. Further studies using rigorous epidemiological methods-including careful control for age, sex, ethnicity, and cigarette smoking-will be required to determine the presence and magnitude of the risk of COPD in PI MZ individuals as a group and in relevant subgroups. It will be important to examine the interaction between PI MZ genotype and cigarette smoking to accurately quantify risk in both smokers and non-smokers. Future studies using other COPD related phenotypes, such as quantitative radiographic measures of emphysema, may also identify clinically relevant subgroups.

\section{ACKNOWLEDGEMENTS}

The authors thank Drs Anne Tybjærg-Hansen, Peter Lange, and Jørgen Vestbo for their helpful suggestions and Dr Clare Ramsey for her assistance with translation from French.

\section{Authors' affiliations}

C P Hersh, N P Ly, C S Berkey, E K Silverman, Channing Laboratory, Department of Medicine, Brigham and Women's Hospital and Harvard Medical School, Boston, MA, USA

M Dahl, B G Nordestgaard, Department of Clinical Biochemistry, Herlev University Hospital, Copenhagen, Denmark

This study was supported by National Institutes of Health grants T32HL07427 and R01-HL68926 and by grants from the Danish Lung Association and the Danish Heart Foundation.

C P Hersh and M Dahl contributed equally to this report.

\section{REFERENCES}

1 National Heart, Lung, and Blood Institute. Morbidity and mortality: 2002 chart book on cardiovascular, lung, and blood diseases. Bethesda, MD: National Institutes of Health, 2002.

2 Lomas DA, Silverman EK. The genetics of chronic obstructive pulmonary disease. Respir Res 2001;2:20-6.

3 Blanco I, Bustillo EF, Rodriguez MC. Distribution of alpha 1-antitrypsin PI S and PI Z frequencies in countries outside Europe: a meta-analysis. Clin Genet 2001;60:431-41.

4 American Thoracic Society. Guidelines for the approach to the patient with severe hereditary alpha-1-antitrypsin deficiency. Am Rev Respir Dis 1989;140:1494-7

5 Mittman C. The PiMZ phenotype: is it a significant risk factor for the development of chronic obstructive lung disease? Am Rev Respir Dis 1978; 118:649-52.

6 Barker AF, D'Silva RG, Buist AS. Lung function and alpha 1-AT deficiency. In: Crystal RG, ed. Alpha 1-antitrypsin deficiency: biology, pathogenesis, clinical manifestations, therapy. New York: Marcel Dekker, 1996:245-57.

7 Sandford AJ, Weir TD, Pare PD. Genetic risk factors for chronic obstructive pulmonary disease. Eur Respir J 1997;10:1380-91.

8 de Serres FJ. Worldwide racial and ethnic distribution of alpha 1-antitrypsin deficiency: summary of an analysis of published genetic epidemiologic surveys. Chest 2002;122:1818-29.

9 DerSimonian R, Laird N. Meta-analysis in clinical trials. Control Clin Trials 1986;7:177-88.

10 Egger M, Smith GD, Schneider M, et al. Bias in meta-analysis detected by a simple, graphical test. BMJ 1997;315:629-34. 
11 Chan-Yeung M, Ashley M, Corey P, et al. Pi phenotypes and the prevalence of chest symptoms and lung function abnormalities in workers employed in dusty industries. Am Rev Respir Dis 1978;117:239-45.

12 Abboud RT, Rushton JM, Grzybowski S. Interrelationships between neutrophil elastase, serum alpha ${ }_{1}$-antitrypsin, lung function and chest radiography in patients with chronic airflow obstruction. Am Rev Respir Dis 1979;120:31-40.

13 Bartmann K, Fooke-Achterrath M, Koch G, et al. Heterozygosity in the Pisystem as a pathogenetic cofactor in chronic obstructive pulmonary disease (COPD). Eur J Respir Dis 1985:66:284-96.

14 Cox DW, Hoeppner VH, Levison H. Protease inhibitors in patients with chronic obstructive pulmonary disease: the alpha 1-antitrypsin heterozygote controversy. Am Rev Respir Dis 1976;113:601-6.

15 Dahl M, Tybjaerg-Hansen $A$, Lange $P$, et al. Change in lung function and morbidity from chronic obstructive pulmonary disease in alpha-1-antitrypsin MZ heterozygotes: a longitudinal study of the general population. Ann Intern Med 2002; 136:270-9.

16 Eriksson S, Lindell SE, Wiberg R. Effects of smoking and intermediate alpha 1-antitrypsin deficiency (PiMZ) on lung function. Eur J Respir Dis 1985;67:279-85.

17 Barnett TB, Gottovi D, Johnson AM. Protease inhibitors in chronic obstructive pulmonary disease. Am Rev Respir Dis 1975;111:587-93.

18 Fagerhol MK, Hauge HE. Serum Pi types in patients with pulmonary diseases. Acta Allergol 1969:24:107-14.

19 Girard F, Aug F, Camara M, et al. Pulmonary abnormality and alpha 1antitrypsin heterozygote deficiency in a working population. Bull Eur Physiopathol Respir 1978;14:11-22.

20 Gulsvik A, Fagerhol MK. Alpha 1-antitrypsin phenotypes and obstructive lung disease in the city of Oslo. Scand J Respir Dis 1979;60:267-74.

21 Hall WJ, Hyde RW, Schwartz RH, et al. Pulmonary abnormalities in intermediate alpha-1-antitrypsin deficiency. J Clin Invest 1976;58:1069-77.

22 Horne SL, Tennent RK, Cockcroft DW, et al. Pulmonary function in Pi M and MZ grainworkers. Chest 1986:89:795-9.

23 Klayton R, Fallat $R$, Cohen $A B$. Determinants of chronic obstructive pulmonary disease in patients with intermediate levels of alphal-antitrypsin. Am Rev Respir Dis 1975; 112:71-5.

24 Kueppers F, Donhardt A. Obstructive lung disease in heterozygotes for alpha-1 antitrypsin deficiency. Ann Intern Med 1974;80:209-12.

25 Kueppers F, Miller RD, Gordon H, et al. Familial prevalence of chronic obstructive pulmonary disease in a matched pair study. Am J Med 1977;63:336-42.

26 Lieberman J, Winter B, Sastre A. Alpha 1-antitrypsin Pi-types in 965 COPD patients. Chest 1986;89:370-3

27 Matzen RN, Bader PI, Block WD. $\alpha 1$-Antitrypsin deficiency in clinic patients. Ann Clin Res 1977;9:88-92.

28 Morse JO, Lebowitz MD, Knudson RJ, et al. Relation of protease inhibitor phenotypes to obstructive lung diseases in a community. N Engl J Med 1977;296: 1190-4.

29 Poller W, Meisen C, Olek K. DNA polymorphisms of the alpha 1-antitrypsin gene region in patients with chronic obstructive pulmonary disease. Eur $J$ Clin lnvest 1990;20:1-7.

30 Sandford AJ, Weir TD, Spinelli JJ, et al. Z and S mutations of the alpha 1antitrypsin gene and the risk of chronic obstructive pulmonary disease. Am J Respir Cell Mol Biol 1999;20:287-91.

31 Talamo RC, Langley CE, Levine BW, et al. Genetic vs. quantitative analysis of serum alpha 1-antitrypsin. N Engl J Med 1972;287:1067-9.

32 Webb DR, Hyde RW, Schwartz RH, et al. Serum alpha 1-antitrypsin variants. Prevalence and clinical spirometry. Am Rev Respir Dis 1973;108:918-25.

33 Alvarez-Granda L, Cabero-Perez MJ, Bustamante-Ruiz A, et al. PI SZ phenotype in chronic obstructive pulmonary disease. Thorax 1997; 52:659-61

34 Cohen BH, Ball WC, Bias WB, et al. A genetic-epidemiologic study of chronic obstructive pulmonary disease. I. Study design and preliminary observations. Johns Hopkins Med J 1975;137:95-104

35 Eriksson S, Moestrup T, Hagerstrand I. Liver, lung and malignant disease in heterozygous (Pi MZ) alpha 1-antitrypsin deficiency. Acta Med Scand 1975; 198:243-7.

36 Guenter CA, Welch MH, Ferguson S, et al. Alpha-1-antitrypsin deficiency: heterozygosity, intermediate levels, and pulmonary disease. Chest 1971;5916S

37 Gupta SP, Pande JN, Guleria JS. Pulmonary emphysema and alpha-1 antitrypsin deficiency. Indian J Med Res 1977;66:127-32.

38 Janus ED. Alpha 1-antitrypsin Pi types in COPD patients. Chest 1988;94:446-7.

39 Kambe M, Morishita K, Tsubokura T, et al. A study on the lung function in alpha 1-antitrypsin-deficient (PiMZ) patients. Hiroshima J Med Sci 1993;42:41-5.

40 Madison R, Mittman C, Afifi AA, et al. Risk factors for obstructive lung disease. Am Rev Respir Dis 1981;124:149-53.

41 Mittman C, Lieberman J, Marasso F, et al. Smoking and chronic obstructive lung disease in alpha-1-antitrypsin deficiency. Chest 1971;60:214-21.

42 Shah AC, Dixit SD, Billimoria FP, et al. Occurrence of alpha 1-antitrypsin deficiency in normal healthy Indians and in patients with various pulmonary diseases. J Indian Med Assoc 1983;81:79-82.

43 Szczeklik A, Stankowska K, Frydecka I. Cardiopulmonary function in $\alpha_{1}$ antitrypsin heterozygotes exposed to severe air pollution. Am Rev Respir Dis 1973; 107:289-91.

44 Talamo RC, Allen JD, Kahan MG, et al. Hereditary alpha-1-antitrypsin deficiency. N Engl J Med 1968;278:345-51

45 Varpela E, Salorinne Y. Respiratory disease profile in 22 patients with alpha 1-antitrypsin deficiencies. Scand J Respir Dis Suppl 1974;89:251-60.
46 Welch MH, Reinecke ME, Hammarsten JF, et al. Antitrypsin deficiency in pulmonary disease: the significance of intermediate levels. Ann Intern Med 1969;71:533-42.

$47 \mathrm{Amin} \mathbf{M}$. The role of alpha 1-antitrypsin in generating chronic obstructive pulmonary disorder. Respirology 2000;5:S39-S43.

48 Berend N. Epidemiological survey of chronic obstructive pulmonary disease and alpha-1-antitrypsin deficiency in Australia. Respirology 2001;6(Suppl):S21-5.

49 Camara M, Martin JP. Alpha 1-antitrypsin deficiency and its repercussions in pulmonary pathophysiology. Bull Eur Physiopathol Respir 1978;14:91-124.

50 Haack DG. Interactions of neutrophil elastase, serum trypsin inhibitory activity, and smoking history as risk factors for chronic obstructive pulmonary disease in patients with $M M, M Z$, and ZZ phenotypes for alphal-antitrypsin. Am Rev Respir Dis 1978;117:812-3.

51 Hutchison DC. Homozygous and heterozygous alpha-1-antitrypsin deficiency: prevalence in pulmonary emphysema. Proc $R$ Soc Med 1976;69:130-1.

52 Kauffmann F. Genetics of chronic obstructive pulmonary diseases. Searching for their heterogeneity. Bull Eur Physiopathol Respir 1984;20:163-210.

53 Lieberman J, Colp C. A role for intermediate, heterozygous alpha 1antitrypsin deficiency in obstructive lung disease. Chest 1990;98:522-3.

54 Madison R, Zelman R, Mittman C. Inherited risk factors for chronic lung disease. Chest 1980;77:255-7.

55 Mittman C, Barbela T, Lieberman J. Alpha 1-antitrypsin deficiency as an indicator of susceptibility to pulmonary disease. J Occup Med 1973;15:33-8.

56 Shim YS. Epidemiological survey of chronic obstructive pulmonary disease and alpha-1 antitrypsin deficiency in Korea. Respirology $2001 ; 6$ (Suppl):S9-1 1

57 Zhu YJ. Epidemiological survey of chronic obstructive pulmonary disease and alpha-1-deficiency in China. Respirology 2001;6(Suppl):S13-5.

58 Bruun-Petersen K, Bruun-Petersen G, Dahl R, et al. Alpha 1-antitrypsin alleles in patients with pulmonary emphysema, detected by DNA amplification (PCR) and oligonucleotide probes. Eur Respir J 1992;5:531-7.

59 Gelb AF, Klein E, Lieberman J. Pulmonary function in nonsmoking subjects with alphal antitrypsin deficiency (MZ phenotype). Am J Med 1977;62:93-8.

60 Larsson C, Dirksen H, Sundstrom G, et al. Lung function studies in asymptomatic individuals with moderately (Pi SZ) and severely (Pi Z) reduced levels of alphal-antitrypsin. Scand J Respir Dis 1976;57:267-80

61 Mittman C, Barbela T, Lieberman J. Antitrypsin deficiency and abnormal protease inhibitor phenotypes. Arch Environ Health 1973;27:201-6.

62 Mittman C, Lieberman J, Rumsfeld J. Prevalence of abnormal protease inhibitor phenotypes in patients with chronic obstructive lung disease. Am Rev Respir Dis 1974;109:295-6.

63 Piitulainen E, Sveger T. Effect of environmental and clinical factors on lung function and respiratory symptoms in adolescents with alpha-1-antitrypsin deficiency. Acta Paediatr 1998;87:1120-4.

64 Sandford AJ, Chagani T, Weir TD, et al. Susceptibility genes for rapid decline of lung function in the lung health study. Am J Respir Crit Care Med 2001:163:469-73.

65 Seersholm N, Kok-Jensen A. Intermediate alpha 1-antitrypsin deficiency PiSZ: a risk factor for pulmonary emphysema? Respir Med 1998;92:241-5.

66 Tarjan E, Magyar P, Vaczi Z, et al. Longitudinal lung function study in heterozygous PiMZ phenotype subjects. Eur Respir J 1994;7:2199-204.

67 Wencker M, Marx A, Konietzko N, et al. Screening for alpha-1-Pi deficiency in patients with lung diseases. Eur Respir J 2002;20:319-24.

68 Cooper DM, Hoeppner V, Cox D, et al. Lung function in alpha-1-antitrypsin heterozygotes (Pi type MZ). Am Rev Respir Dis 1974;110:708-15.

69 Hepper NG, Muhm JR, Sheehan WC, et al. Roentgenographic study of chronic obstructive pulmonary disease by alphal-antitrypsin phenotype. Mayo Clin Proc 1978;53:166-72.

70 Johnson TF, Reisman RE, Arbesman CE, et al. Obstructive airway disease associated with heterozygous alpha-1-antitrypsin deficiency. J Allergy Clin Immunol 1976:58:69-75.

71 Kabiraj MU, Simonsson BG, Groth S, et al. Bronchial reactivity, smoking, and alphal-antitrypsin. A population-based study of middle-aged men. Am Rev Respir Dis 1982;126:864-9.

72 Klasen EC, Biemond I, Laros CD. Alpha 1-antitrypsin deficiency and the flaccid lung syndrome. The heterozygote controversy. Clin Genet 1986;29:21 1-5

73 Larsson C, Eriksson S, Dirksen H. Smoking and intermediate alpha1antitrypsin deficiency and lung function in middle-aged men. BMJ 1977;2:922-5.

74 Lebowitz MD, Knudson RJ, Morse JO, et al. Closing volume and flow volume abnormalities in alpha(1)-antitrypsin phenotype groups in a community population. Am Rev Respir Dis 1978;117:179-81.

75 McDonagh DJ, Nathan SP, Knudson RJ, et al. Assessment of alpha-1antitrypsin deficiency heterozygosity as a risk factor in the etiology of emphysema. Physiological comparison of adult normal and heterozygous protease inhibitor phenotype subjects from a random population. $J$ Clin Invest 1979;63:299-309.

76 Ostrow DN, Cherniack RM. The mechanical properties of the lungs in intermediate deficiency of alpha 1-antitrypsin. Am Rev Respir Dis 1972; 106:377-83

77 Pride NB, Tattersall SF, Pereira RP, et al. Lung distensibility and airway function in intermediate alpha 1-antitrypsin deficiency (PiMZ). Chest 1980;77:253-5.

78 Ostrow DN, Manfreda J, Dorman T, et al. Alphal-antitrypsin phenotypes and lung function in a moderately polluted northern Ontario community. Can Med Assoc J 1978;1 18:669-72. 
79 Bencze K, Sabatke L, Fruhmann G. Alpha 1-antitrypsin: the PiMM subtypes Do they play a role in development of chronic obstructive pulmonary diseases? Chest 1980;77:761-3.

80 Gishen P, Saunders AJ, Tobin MJ, et al. Alpha 1-antitrypsin deficiency: the radiological features of pulmonary emphysema in subjects of $\mathrm{Pi}$ type $\mathrm{Z}$ and $\mathrm{Pi}$ type SZ: a survey by the British Thoracic Association. Clin Radiol 1982;33:371-7.

81 Hutchison DC, Tobin MJ, Cook PJ. Alpha 1 antitrypsin deficiency: clinical and physiological features in heterozygotes of $\mathrm{Pi}$ type SZ. A survey by the British Thoracic Association. Br J Dis Chest 1983;77:28-34.

82 Roberts A, Kagan A, Rhoads GG, et al. Antitrypsin and chronic obstructive pulmonary disease among Japanese-American men. Chest 1977;72:489-91.

83 Turino GM, Barker AF, Brantly ML, et al. Clinical features of individuals with $\mathrm{PI}$ SZ phenotype of alpha 1-antitrypsin deficiency. $\alpha 1$-Antitrypsin Deficiency Registry Study Group. Am J Respir Crit Care Med 1996;154:1718-25.

84 Kauffmann F, Kleisbauer JP, Cambon-De-Mouzon A, et al. Genetic markers in chronic air-flow limitation. A genetic epidemiologic study. Am Rev Respir Dis 1983:127:263-9.

85 Seyama K. State of alpha 1-antitrypsin deficiency in Japan. Respirology 2000;5:S35-8

86 Bruce RM, Cohen BH, Diamond EL, et al. Collaborative study to assess risk of lung disease in Pi MZ phenotype subjects. Am Rev Respir Dis 1984;130:386-90.

87 Buist AS, Sexton GJ, Azzam AM, et al. Pulmonary function in heterozygotes

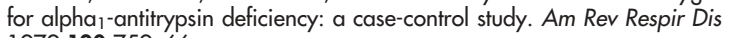
1979;120:759-66.

88 Cole RB, Nevin NC, Blundell G, et al. Relation of alpha-1-antitrypsin phenotype to the performance of pulmonary function tests and to the prevalence of respiratory illness in a working population. Thorax 1976;31:149-57.

89 de Hamel FA, Carrell RW. Heterozygous alpha 1-antitrypsin deficiency: a longitudinal lung function study. NZ Med J 1981;94:407-10.

90 Gerblich AA, Kleinerman J, Rynbrandt DJ, et al. Pi-Z phenotypes in a pulmonary clinic. Their prevalence and physiologic state. Am J Clin Pathol 1978;69:509-13.

91 Horton FO 3rd, Mackenthun AV, Anderson PS Jr, et al. Alpha 1 antitrypsin heterozygotes (Pi type MZ). A longitudinal study of the risk of development of chronic air flow limitation. Chest 1980;77:261-4.

92 Kozarevic D, Laban M, Budimir M, et al. Intermediate alphal-antitrypsin deficiency and chronic obstructive pulmonary disease in Yugoslavia. Am Rev Respir Dis 1978;117:1039-43.

93 Siekmeier R, Schiller-Scotland CF. Convective gas mixing, airway dimensions and lung function parameters in patients homo- or heterozygote for hereditary alpha-1-antitrypsin deficiency. Toxicol Lett 1998;96-97:325-33

94 Tattersall SF, Pereira RP, Hunter D, et al. Lung distensibility and airway function in intermediate alpha 1-antitrypsin deficiency (Pi MZ). Thorax 1979;34:637-46.

95 Cohen BH, Ball WC Jr, Brashears S, et al. Risk factors in chronic obstructive pulmonary disease (COPD). Am J Epidemiol 1977; 105:223-32.

96 Colp C, Talavera W, Goldman D, et al. Profile of bronchospastic disease in Puerto Rican patients in New York City. A possible relationship to alpha 1 antitrypsin variants. Arch Intern Med 1990;150:2349-54.

97 Corbo GM, Forastiere F, Agabiti N, et al. Passive smoking and lung function in alpha(1)-antitrypsin heterozygote schoolchildren. Thorax 2003:58:237-41.

98 Galdston M, Melnick EL, Goldring RM, et al. Interactions of neutrophil elastase, serum trypsin inhibitory activity, and smoking history as risk factors for chronic obstructive pulmonary disease in patients with $M M, M Z$, and $Z Z$ phenotypes for alpha-antitrypsin. Am Rev Respir Dis 1977;1 16:837-46.

99 Kueppers F, Fallat R, Larson RK. Obstructive lung disease and alpha-1antitrypsin deficiency gene heterozygosity. Science 1969;165:899-901.
100 Kueppers F. Alpha-1-antitrypsin: 1. Evidence for two genes causing low concentrations in serum; 2 . Association of heterozygosity and chronic obstructive lung disease. Chest 1971;59(Suppl): 15S

101 Fallat R, Powell M, Kueppers F, et al. Chronic obstructive pulmonary disease with intermediate alpha-1-antitrypsin deficiency. Chest 1971;59(Suppl):20S.

102 Hepper NG, Black LF, Gleich GJ, et al. The prevalence of alpha 1-antitrypsin deficiency in selected groups of patients with chronic obstructive lung disease. Mayo Clin Proc 1969;44:697-710.

103 Lieberman J. Heterozygous and homozygous alpha-antitrypsin deficiency in patients with pulmonary emphysema. N Engl J Med 1969;281:279-84.

104 Lieberman J, Mittman C, Schneider AS. Screening for homozygous and heterozygous alpha 1-antitrypsin deficiency. Protein electrophoresis on cellulose acetate membranes. JAMA 1969:210:2055-60.

105 Smith JP, Falk GA, Siskind GW. Serum immunoglobulins and alpha-1antitrypsin: variation with clinical type of chronic obstructive pulmonary disease. Chest 1971;59(Suppl): 17S.

106 Sveger T. Plasma protease inhibitors in alpha 1-antitrypsin-deficient children. Pediatr Res 1985;19:834-5.

107 Seersholm N, Wilcke JT, Kok-Jensen A, et al. Risk of hospital admission for obstructive pulmonary disease in alpha(1)-antitrypsin heterozygotes of phenotype PiMZ. Am J Respir Crit Care Med 2000;161:81-4.

108 Silva GE, Sherrill DL, Guerra S, et al. A longitudinal study of alpha ${ }_{1}^{-}$ antitrypsin phenotypes and decline in $\mathrm{FEV}_{1}$ in a community population. Chest 2003;123:1435-40.

109 Dahl M, Nordestgaard BG, Lange P, et al. Molecular diagnosis of intermediate and severe alpha(1)-antitrypsin deficiency: $M Z$ individuals with chronic obstructive pulmonary disease may have lower lung function than MM individuals. Clin Chem 2001;47:56-62.

110 Miller RD, Hepper NG, Kueppers F, et al. Host factors in chronic obstructive pulmonary disease in an upper Midwest rural community. Design, case selection, and clinical characteristics in a matched-pair study. Mayo Clin Proc 1976;51:709-15.

111 Shigeoka JW, Hall WJ, Hyde RW, et al. The prevalence of alpha-antitrypsin heterozygotes ( $\mathrm{Pi} M Z$ ) in patients with obstructive pulmonary disease. Am Rev Respir Dis 1976;114:1077-84.

112 Vance JC, Hall WJ, Schwartz RH, et al. Heterozygous alpha-1-antitrypsin deficiency and respiratory function in children. Pediatrics 1977;60:263-72

113 von Ehrenstein OS, von Mutius E, Maier E, et al. Lung function of school children with low levels of alpha-1-antitrypsin and tobacco smoke exposure. Eur Respir J 2002;19:1099-106.

114 Silverman EK, Province MA, Rao DC, et al. A family study of the variability of pulmonary function in alpha 1-antitrypsin deficiency. Quantitative phenotypes. Am Rev Respir Dis 1990;142:1015-21.

115 Duncan PE, Griffin JP. Physiological studies in a large sibship with antitrypsin deficiency. Br J Dis Chest 1975;69:107-17.

116 Pritchard JK, Rosenberg NA. Use of unlinked genetic markers to detect population stratification in association studies. Am J Hum Genet 1999:65:220-8

117 Glasziou P, Irwig L, Bain C, et al. How to review the evidence: systematic identification and review of the scientific literature. Canberra, Australia: National Health and Medical Research Council, 1999

118 Silverman EK, Palmer U. Case-control association studies for the genetics of complex respiratory diseases. Am J Respir Cell Mol Biol 2000;22:645-8.

119 Silverman EK, Miletich JP, Pierce JA, et al. Alpha-1-antitrypsin deficiency. High prevalence in the St Lovis area determined by direct population screening. Am Rev Respir Dis 1989;140:961-6.

120 Rothman KJ, Greenland S. Case-control studies. In: Rothman KJ Greenland S, eds. Modern epidemiology.2nd ed. Philadelphia: Lippincott Williams \& Wilkins, 1998:93-114.

121 Novoradovsky A, Brantly ML, Waclawiw MA, et al. Endothelial nitric oxide synthase as a potential susceptibility gene in the pathogenesis of emphysema in alpha-1-antitrypsin deficiency. Am J Respir Cell Mol Biol 1999;20:441-7. 